\title{
13. DOWNHOLE MAGNETIC FIELD MEASUREMENTS AND PALEOMAGNETISM, HOLE 504B, COSTA RICA RIDGE ${ }^{1}$
}

\author{
H. Kinoshita, ${ }^{2}$ T. Furuta, ${ }^{3}$ and J. Pariso ${ }^{4}$
}

\begin{abstract}
Downhole magnetic field measurements were conducted in Hole 504B on the Costa Rica Ridge during ODP Leg 111. Three magnetic groups within oceanic basement at this site are tentatively defined, based on the interval mean values of the downhole magnetic field. Statistical analyses show that there are significant differences in the inclinations of natural remanent magnetization (NRM) among the three magnetic groups. Although this could be caused by various factors, we explain the inclination difference among the three groups by simple tectonic displacements of basement by faulting after its formation, about 5.9 Ma ago. Based on the intensities of NRM and inclinations measured in the basement core samples drilled in Hole 504B on DSDP Legs 69, 70, and 83 and ODP Leg 111, the investigated section of basement formation can be divided into three or four magnetic zones that parallel the zones defined by the downhole magnetic field, alteration, and lithology. Downhole magnetic field and paleomagnetic data generally correlate positively, in spite of some discrepancies. The magnetic susceptibility values of the core samples were used to derive the insitu NRM from the downhole magnetic field data.
\end{abstract}

\section{INTRODUCTION}

Hole 504B has been the target of five Deep Sea Drilling Project (DSDP) and Ocean Drilling Program (ODP) legs from 1979 through 1986; of these, logging programs only were performed on Leg 92. A schematic diagram of the petrological structure of Hole 504B is shown in Figure 1. This hole reaches nearly $1300 \mathrm{~m}$ into oceanic basement, within a few hundred meters of the transition between basaltic Layer 2C and gabbroic Layer 3 (Becker, Sakai, et al., 1988). Hole 504B provides us with the opportunity to measure the downhole magnetic fields for comparison with the rock magnetic values measured on recovered core samples.

The magnetization of the oceanic crust plays a significant role in understanding the development of magnetic source layers and the growth and decay of magnetic polarization and intensity of oceanic basement (as discussed by Furuta, 1987). The rock magnetic properties of Hole 504B have been previously studied by Pechersky et al. (1979), Furuta (1983), Furuta and Levi (1983), Facey et al. (1985), Kinoshita et al. (1985), and Smith and Banerjee (1986).

This paper describes results of downhole magnetic field measurements and summarizes the paleomagnetic data from Leg 111 as well as the previous legs at Hole 504B. For the derivation of in-situ NRM from the logging data, we used stable NRM data from our measurements of the recovered cores. As subsequently explained, the elementary inclination and susceptibility values of our data were obtained using different methods than those of the other investigators. The downhole magnetic field data are converted to apparent in-situ NRM by use of the susceptibilities of the cores. The results suggest some block displacement of basement layers, perhaps by tectonic faulting in upper part of oceanic basement.

\footnotetext{
${ }^{1}$ Becker, K., Sakai, H., et al., 1989. Proc. ODP, Sci. Results, 111: College Station, TX (Ocean Drilling Program).

2 Department of Earth Sciences, Faculty of Sciences, Chiba University, 1-33 Yayoi-cho, Chiba, 260, Japan.

${ }^{3}$ Ocean Research Institute, University of Tokyo, 1-15-1 Minamidai, Tokyo, 164, Japan.

${ }^{4}$ School of Oceanography, University of Washington, Seattle, WA 98105.
}

\section{PREVIOUS DOWNHOLE MAGNETIC MEASUREMENTS}

The vertical component of the magnetic field was first measured downhole by Ponomarev and Nekharoshkov (1983) during Legs 68 and 69, using a three-component magnetic tool in Hole 501 and in the upper part of Hole 504B. Their results show sharp jumps in the vertical component of the magnetic field. Downhole magnetic field measurements from several other DSDP and ODP holes generally agree well with the paleomagnetic results for rock samples from the same holes (Ponomarev and Nekharoshkov, 1983; Johnson, 1979; Hamano and Kinoshita, in press). Examples of similar experiments were presented by Johnson and Pariso (1985; H. P. Johnson, pers. comm., 1987). However, local tectonic problems around Hole 504B have received little discussion.

\section{MEASUREMENTS OF THE DOWNHOLE MAGNETIC FIELD}

The external field is framed as the present geomagnetic field at the site obtained from the International Geomagnetic Reference Field (IGRF; IAGA Division I, Working Group 1, 1985) plus the local anomaly field component. The local anomaly field is defined here as an averaged downhole magnetic field, for the interval from the sediment/basement interface to the bottom of magnetic logging, less the IGRF. The 1985 IGRF field for this site is given in Table 1.

During Leg 111, the downhole magnetic field in Hole 504B was measured with a Japanese magnetometer system and a Schlumberger inclinometer at temperatures from about $2^{\circ} \mathrm{C}$ at the mud line to about $150^{\circ} \mathrm{C}$ at the bottom of hole. After the logging run, the Japanese magnetometer was found to have withstood the heat poorly. Therefore, the downhole magnetic field data used here were obtained with the Schlumberger system, which was run in combination with the lithodensity logging tool. Figure 2 presents the results of these measurements averaged for 1$\mathrm{m}$ intervals throughout the hole below the sediment/basalt interface at $274.5 \mathrm{~m}$ below seafloor (mbsf). Digital data were recorded every $15-20 \mathrm{~cm}$ and are averaged over $1-\mathrm{m}$ intervals to reduce the spiky signals resulting from unpredictable reasons. Statistical measures were applied to the running mean values of the downhole magnetic field, and the results are given in Table 2. 
A

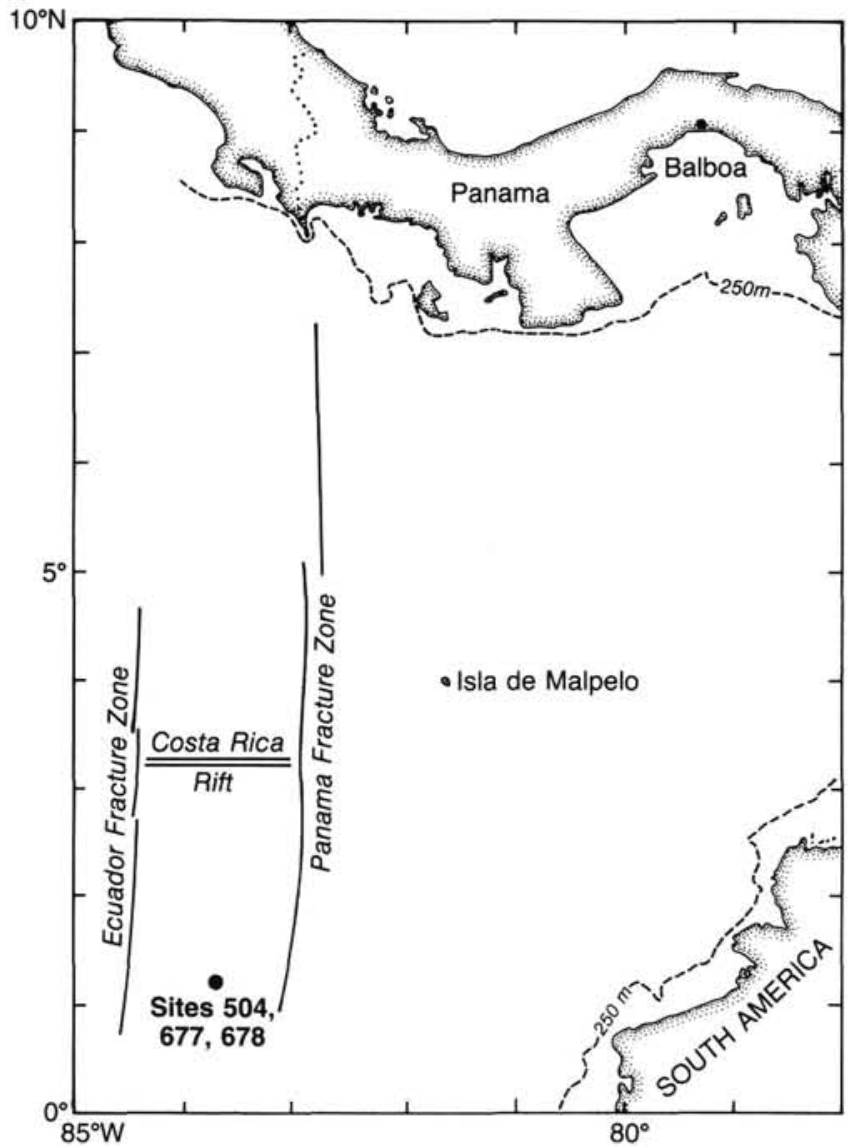

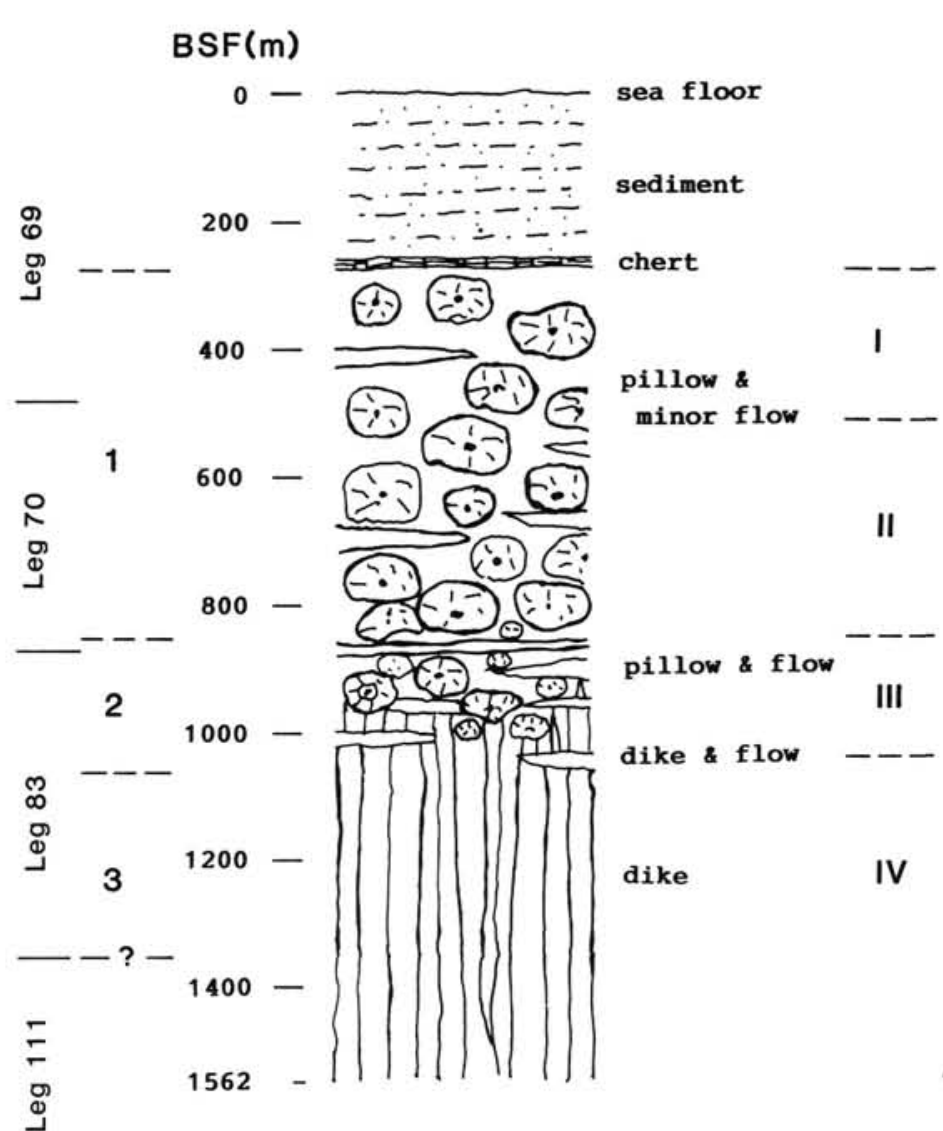

Figure 1. A. Location of Site 504 in the eastern Pacific. B. Lithologic zones 1 through 3 from petrographic descriptions and magnetic groups I through IV presented here of basement formation in Hole 504B.

Table 1. IGRF field components at Site 504.

\begin{tabular}{ll}
\hline \multicolumn{1}{c}{ Component } & \multicolumn{1}{c}{ Value } \\
\hline Total force & $32326 \mathrm{nT}$ \\
Vertical field & $13350 \mathrm{nT}$ \\
Inclination (northward dipping) & $24.4^{\circ}$ \\
Declination (eastward deflected) & $3.2^{\circ}$ \\
\hline
\end{tabular}

Important findings from these measurements and calculations are as follows:

1. The measured inclination throughout the basement section of Hole 504B lies between $34^{\circ}$ and $48^{\circ}$, in contrast to the $24.4^{\circ}$ inclination of the 1985 IGRF field at the site.

2. There are more than 10 sets of coincidental changes in the field strength and the inclination.

3. Based on variations of the magnetic field, the data can be divided into three zones:

Top zone: highly variable intensity, with a maximum amplitude of $5000 \mathrm{nT}$.

Middle zone: steady field intensity and only a couple of spikes with an amplitude of $2000 \mathrm{nT}$.

Bottom zone: variable intensity, with a maximum amplitude of $2500 \mathrm{nT}$.

4. Cross plots of the total field intensity and inclination also show differences in correlation factors in these three zones (Fig. 3):
Top zone: negative.

Middle zone: no correlation.

Bottom zone: weakly negative.

The three zones defined by the downhole magnetic field correspond to the major lithologic zones. The top magnetic zone corresponds to pillow lavas, the middle zone to the transition, and the bottom zone to the sheeted dikes (Fig. 1).

\section{DEDUCTION OF IN-SITU MAGNETIZATION}

The measured downhole inclination values must be corrected for an artificial bias field that might have been added to the actual downhole magnetic field, based on a comparison measurement run in Hole 395A using both the Japanese and Schlumberger tools (Hamano and Kinoshita, in press). The experiment in Hole $395 \mathrm{~A}$ revealed that the inclination derived from the Schlumberger combination tool was systematically biased. The average inclination value measured with the Schlumberger tool was $51.8^{\circ}$ and that measured with the Japanese tool was $42.1^{\circ}$. Both tool values have a standard deviation less than $2.5^{\circ}$, whereas the 1985 IGRF inclination is $42.0^{\circ}$. This comparison run was made at fairly low temperatures $\left(<20^{\circ} \mathrm{C}\right)$ in Hole $395 \mathrm{~A}$. Unfortunately, the higher hole temperatures of up to $150^{\circ} \mathrm{C}$ in Hole 504B prevented us from completing a comparison run between the Schlumberger and Japanese tools because of the latter's temperature sensitivity. Therefore, the downhole magnetic field data measured in Hole 504B with the Schlumberger tool were corrected for the offset between the average magnetic fields 


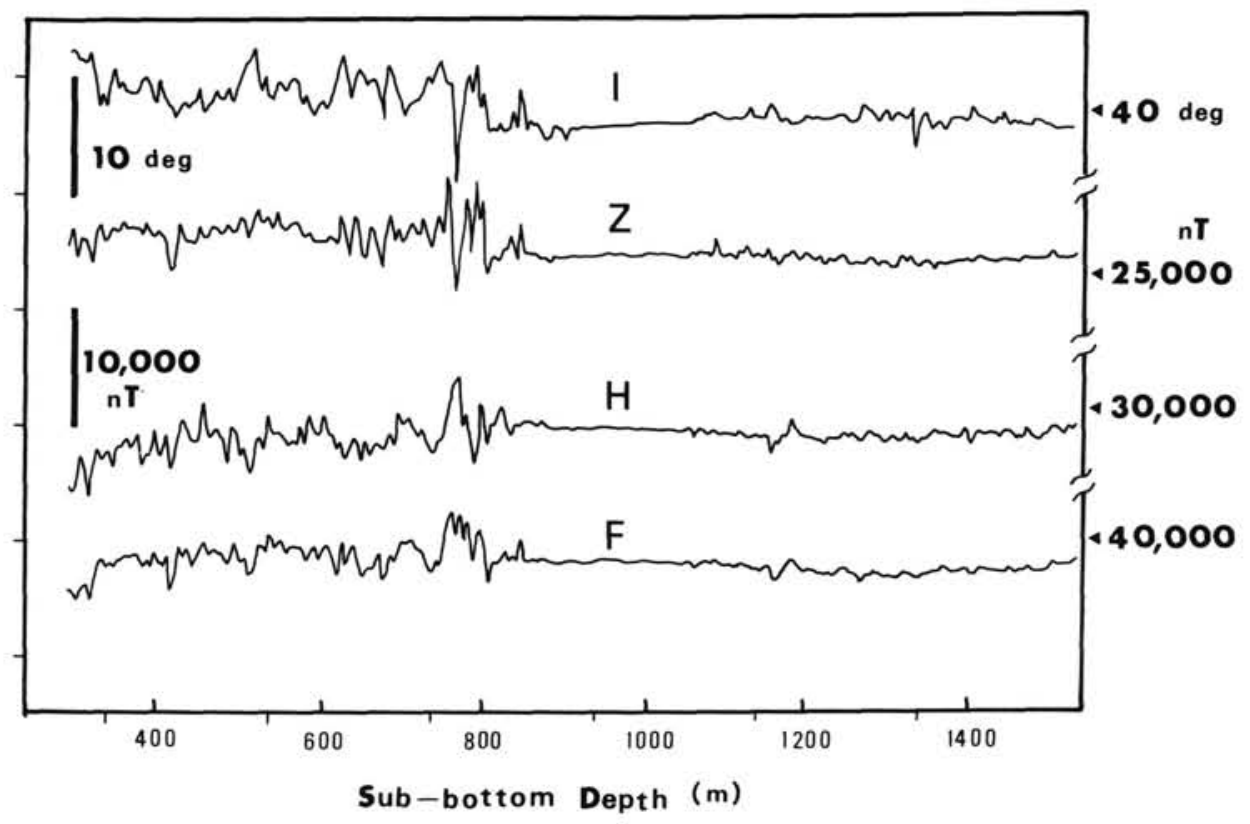

Figure 2. Downhole magnetic field components (averaged over 1-m intervals) plotted vs. sub-bottom depth in Hole 504B. I, Z, H, and F denote inclination, vertical field, horizontal field, and total field, respectively. The amplitude of $\mathrm{I}, \mathrm{Z}, \mathrm{H}$, and $\mathrm{F}$ are given by the thick vertical thick bars on the left side of the figure, and absolute values are given on the right for $\mathrm{I}\left({ }^{\circ} \mathrm{C}\right)$ and the field strengths (nT).

Table 2. Statistical results of the downhole magnetic field components from data averaged over 1-m intervals between 275 and 1525 mbsf, Hole 504B.

\begin{tabular}{lcc}
\hline \multicolumn{1}{c}{ Component } & Average & $\begin{array}{c}\text { Standard } \\
\text { deviation }\end{array}$ \\
\hline Total field (nT) & 44811 & 1490 \\
Horizontal field (nT) & 34080 & 1195 \\
${ }^{\text {a Inclination (degrees) }}$ & 40.0 & 1.9 \\
\hline
\end{tabular}

a Calculated from the horizontal force/total force ratio. Two components in the horizontal plane cannot be determined because of ambiguous rotation of the tool around a vertical axis.

measured in Hole 395A with the Japanese and Schlumberger tools.

The local downhole magnetic field consists of an external (geomagnetic) field and an additional field produced by the inhomogeneous distribution of NRM and susceptibility of materials around the measuring system. In a very simple case, the magnetic sensor hangs in the center of a vertical hole of a fixed round cross section and the magnetic strata are seated in a horizontal plane to infinite extent. The magnetic field around the sensor from a single layer is given in simple analytical form in the Appendix.

The downhole magnetic field is assumed to represent the insitu magnetization of the basement materials nearest to the magnetic sensor. (Theoretical considerations are detailed by Parker and Daniell, 1979.) This is not necessarily true for individual sampled points because the magnetization of basement might be inhomogeneous or switch polarity frequently within a small interval. We smoothed out this irregularity to some extent by taking as many sampling points as possible and by averaging them over $1-\mathrm{m}$ intervals. The 1250 samples are sufficient to allow us to use a statistical evaluation of the in-situ magnetization of the basement materials.
The magnetization of the basement layer $\left(M_{m}\right)$ is the sum of the NRM and the induction of the external field $\left(k F_{\text {ext }}\right)$, where $k$ denotes the magnetic susceptibility of the basement rocks. We have to refer, therefore, to the in-situ magnetic susceptibility to deduce the NRM from the integrated in-situ magnetic field. Downhole susceptibility measurements have not been performed yet in Hole 504B, and we are limited to using available rock magnetic data.

\section{ROCK MAGNETIC DATA OF RECOVERED CORE SAMPLES}

The rock magnetic properties of the cores recovered on Leg 111 are listed in Table 3 and with results from previous legs in Table 4. The entire basement section below $274.5 \mathrm{mbsf}$ in Hole 504B is divided into four magnetic groups, based on the stable inclination (Furuta, 1983; Furuta and Levi, 1983; Kinoshita et al., 1985). Magnetic groups I through IV are defined temporarily by the clustering of average inclination and intensity of NRM with reference to the lithologic units in Figure 1.

The magnetic subunits in Table 3 are defined by changes in inclination. Each subunit is assumed to correspond to a single lava (or dike) sheet. Our statistical calculations were performed on the average values of the subunit. Smith and Banerjee (1986) reported similar results, although they used a single sample for the elementary statistical unit. The stable inclination obtained after alternating field (AF) demagnetization of the core samples is plotted in Figure 4 as a function of depth. Stable inclination values of the upper three magnetic groups (I, II, and III) are predominantly negative, and those of the deepest group (IV) are scattered. Magnetic groups II and III have some isolated steep inclinations.

Figure 5 shows the NRM intensities averaged over each magnetic subunit. The NRM intensity drops abruptly below the boundary between groups II and III. This boundary roughly corresponds to the lithologic boundary between the extrusives and the transition zone (Fig. 1). A schematic illustration of the up/down sense of dip of the NRM inclination of each magnetic subunit is shown in Figure 6. Positive and negative inclinations 

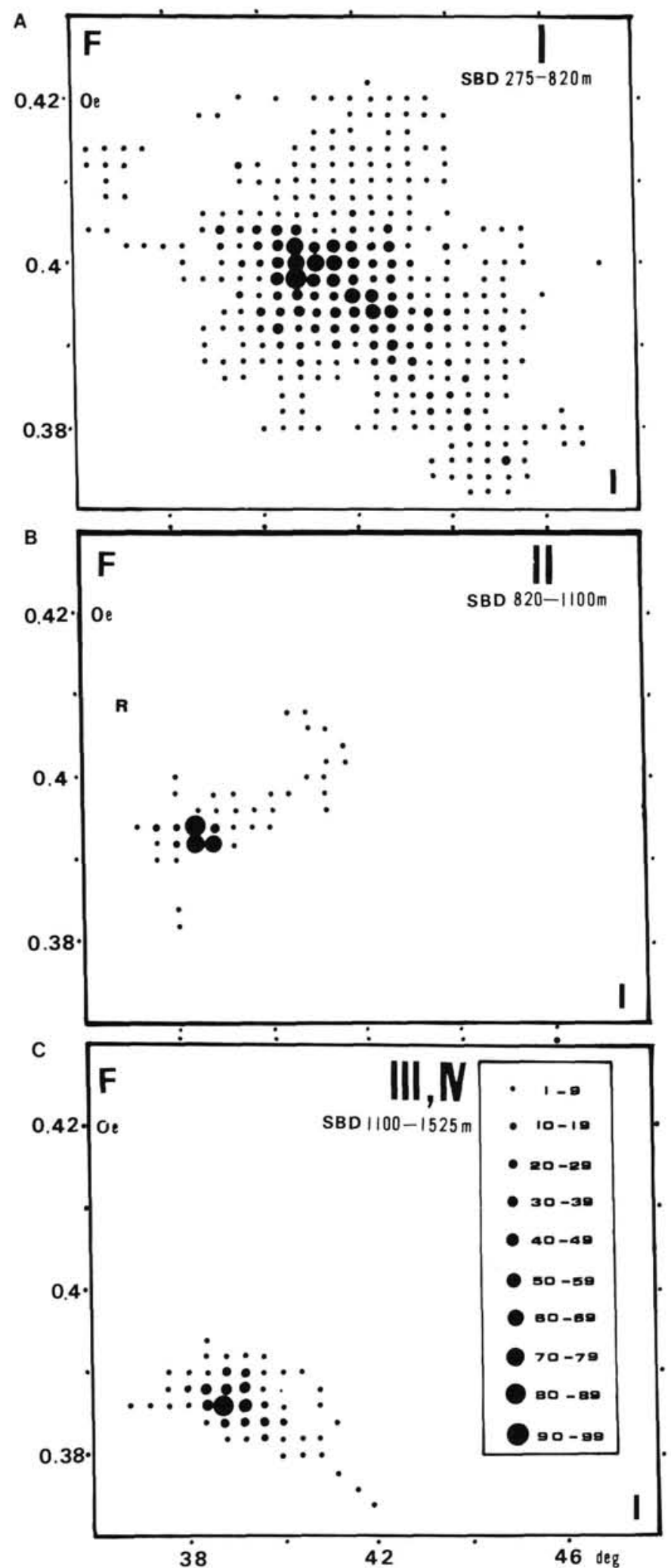

Figure 3. Cross plots of the total downhole magnetic field (F) measurements vs. inclination (I) values for the three magnetic zones defined by changes in field strengths in Hole 504B. The radii of the solid circles represent the frequency of occurrence proportional to the frequency in 10 divisions. A. Top magnetic zone, 275 to $820 \mathrm{~m}$ sub-bottom depth. B. Middle magnetic zone, 820 to $1100 \mathrm{~m}$ sub-bottom depth. C. Bottom magnetic zone, 1100 to $1525 \mathrm{~m}$ sub-bottom depth. combined with NRM intensities are represented by a bar, with negative values to the right and positive values to the left of the center vertical line. The lengths of the bars are proportional to the average NRM intensity of the magnetic subunits.

\section{PALEOMAGNETIC REDUCTION FROM THE DOWNHOLE MAGNETIC FIELD}

The methods used to calculate in-situ NRM from the downhole magnetic field are given in the Appendix. Although there is a slight difference in rock magnetic character between magnetic groups III and IV, we did not find a significant difference in downhole field variation and consider them to be a single group. Therefore, the basement section of Hole 504B is divided into three magnetic groups, and the interval average for both horizontal and vertical components is calculated from $F_{\text {ext }}-F_{504 \mathrm{~B}}$, where $F_{504 \mathrm{~B}}$ denotes magnetic field components averaged throughout the hole (Table 2). The magnetization induced by the external field $\left(k F_{\text {ext }}\right)$ is subtracted to obtain the in-situ NRM (see the Appendix). The calculation was made for two cases, where magnetic susceptibility is (1) zero and (2) an interval average of the data from core samples (Table 5). The geomagnetic field of the site was assumed to have remained still during the downhole magnetic logging.

Determination of the normal or reverse polarity of in-situ magnetization of the basement materials from the logging data was made based on the correlation plots of Figure 3. If the horizontal component, which is the predominant component in Table 2 , decreases-which is equivalent to an increase in inclination-the in-situ NRM can be reversed, and vice versa. There is a similar check for the vertical sense of polarization. The polarity of magnetization thus classified is in good accordance with the results calculated with equations (1) through (3) in the Appendix. The results are listed in comparison with the paleomagnetic NRM of the individual core samples in Table 6.

\section{DISCUSSION AND SUMMARY}

Although there are fairly large differences in the absolute values of inclination between the paleomagnetism of the individual core samples and the logging experiments in each magnetic group (I, II, and III + IV combined), the coherency of the relative change in magnetic orientation obtained by both methods is clear. The discrepancy between the steep inclination values of the downhole magnetic field measurements and the shallow inclination of the core samples from the lower part of Hole 504B may be caused by various factors. Thermal, viscous, pressure, corrosive, precipitation, oxidation, and reduction effects on the NRM may be induced to some extent by drilling. Our data do not allow resolution of an absolute value of deviation of the rock magnetic properties from in-situ properties.

The large difference in average NRM and the high inclinations between the upper and lower parts of Hole 504B can not be explained by simple drilling disturbance. One possible explanation is that the change in inclination is due to a large change in the geomagnetic dipole or nondipole field. It is also possible that collapse or slumping of ridge fragments associated with displacement and tilting of crustal blocks took place when the lithosphere underlying the oceanic crust started moving away from the ridge axis. Block displacement could have been caused by the formation of shear zones in the form of fractures, faults, or tectonic sutures in the upper part of the basement. Other logging data support this latter case (Becker, Sakai, et al., 1988), which we present in Figure 7 as the hypothesized tectonic movement of basement between the Costa Rica Rift and Site 504 drawn on the following tectonic assumptions:

1. The variation of the geomagnetic field is in the limit of the dispersion regime in the lower latitudes of the Pacific area 
Table 3. Summary of the paleomagnetic properties of basalts recovered in Hole 504B on Leg 111. Magnetic subunits are discussed in the text.

\begin{tabular}{|c|c|c|c|c|c|c|c|}
\hline $\begin{array}{l}\text { Core, section, } \\
\text { interval }(\mathrm{cm})\end{array}$ & $\begin{array}{l}\text { Depth } \\
\text { (mbsf) }\end{array}$ & $\begin{array}{c}\text { NRM } \\
\text { intensity } \\
(\mathrm{A} / \mathrm{m})\end{array}$ & $\begin{array}{c}\text { Stable } \\
\text { inclination } \\
\text { (degrees) }\end{array}$ & $\begin{array}{c}\text { Magnetic } \\
\text { susceptibility } \\
\left(\times 10^{-4} \mathrm{G} / \mathrm{Oe}\right)\end{array}$ & $\begin{array}{l}\text { Koenigsberger } \\
\text { ratio }\end{array}$ & $\begin{array}{c}\text { Median } \\
\text { destructive } \\
\text { field } \\
(\mathrm{mT})\end{array}$ & $\begin{array}{l}\text { Magnetic } \\
\text { sub-group }\end{array}$ \\
\hline 142R-1, 6 & 1352.9 & 6.0 & -36.8 & 30.6 & 4.4 & 97 & \\
\hline $142 \mathrm{R}-1,129$ & 1354.1 & 0.03 & 8 & 0.5 & 1.3 & 575 & \\
\hline $142 \mathrm{R}-2,35$ & 1354.7 & 2.6 & - & 16.6 & 3.1 & 575 & \\
\hline $142 \mathrm{R}-2,57$ & 1354.9 & 3.42 & -25.4 & 19.2 & 4.0 & 75 & \\
\hline $142 \mathrm{R}-2,58-60$ & 1354.9 & 3.2 & - & - & - & - & \\
\hline $143 \mathrm{R}-1,6$ & 1359.4 & 4.03 & 17 & 19.8 & 4.1 & 186 & \\
\hline $143 \mathrm{R}-1,67-69$ & 1360.0 & 1.0 & - & - & - & - & \\
\hline 143R-1, 99 & 1360.3 & 0.21 & -23 & 1.9 & 2.1 & 182 & \\
\hline $143 R-1,105$ & 1360.4 & 0.26 & -17.1 & 4.7 & 1.2 & 222 & 25 \\
\hline $143 \mathrm{R}-2,60$ & 1361.4 & 0.9 & -20 & 0.08 & 23.5 & 138 & \\
\hline $144 \mathrm{R}-1,32$ & 1369.0 & 1.58 & - & 15.1 & 2.1 & 147 & \\
\hline $144 \mathrm{R}-1,89$ & 1369.6 & 1.34 & -14.9 & 16.4 & 1.8 & 150 & \\
\hline $145 \mathrm{R}-1,2$ & 1378.3 & 1.93 & -28 & 11.0 & 3.5 & 161 & \\
\hline $145 \mathrm{R}-1,95$ & 1379.2 & 2.35 & -21.6 & 16.3 & 3.2 & 139 & \\
\hline $145 \mathrm{R}-1,111-113$ & 1379.4 & 1.7 & - & - & - & - & \\
\hline $145 \mathrm{R}-2,54$ & 1380.3 & 0.73 & - & 4.9 & 3.0 & 530 & \\
\hline 145R-2, 95-98 & 1380.8 & 2.4 & - & - & - & - & \\
\hline $145 \mathrm{R}-2,123$ & 1381.0 & 2.08 & -22.5 & 11.5 & 1.2 & 120 & \\
\hline $145 \mathrm{R}-3,44$ & 1381.7 & 1.94 & -23.8 & 15.9 & 2.7 & 143 & \\
\hline $145 \mathrm{R}-3,85-88$ & 1382.1 & 2.6 & - & - & - & - & \\
\hline $145 \mathrm{R}-3,129$ & 1382.6 & 2.23 & 12 & 12.2 & 3.7 & 141 & \\
\hline 147R-1, 39 & 1397.8 & 2.18 & 8.2 & 16.1 & 3.0 & 132 & \\
\hline $147 \mathrm{R}-1,63$ & 1398.0 & 2.81 & 13.8 & 18.2 & 3.1 & 118 & \\
\hline $147 \mathrm{R}-2,44$ & 1398.9 & 2.14 & 7.4 & 18.5 & 2.6 & 130 & \\
\hline $147 \mathrm{R}-2,72-74$ & 1398.1 & 2.6 & - & - & - & - & \\
\hline $147 \mathrm{R}-2,76$ & 1399.3 & 2.19 & 20.4 & 20.0 & 2.2 & 89 & \\
\hline $148 \mathrm{R}-1,61$ & 1407.4 & 2.19 & 7.0 & 17.7 & 2.7 & 152 & \\
\hline $148 \mathrm{R}-1,68$ & 1407.5 & 1.74 & 12.0 & 18.6 & 2.1 & 160 & 26 \\
\hline $148 \mathrm{R}-1,71-73$ & 1407.5 & 2.0 & - & - & - & - & \\
\hline $148 \mathrm{R}-2,52$ & 1408.8 & 3.09 & 5 & 18.9 & 3.3 & 130 & \\
\hline $149 \mathrm{R}-1,34$ & 1417.2 & 1.58 & 4.7 & 15.9 & 2 & 172 & \\
\hline $149 \mathrm{R}-1,41-43$ & 1417.3 & 1.6 & - & - & - & - & \\
\hline $149 \mathrm{R}-1,82$ & 1417.7 & 1.65 & 4.9 & 16.9 & 2.2 & 170 & \\
\hline $149 \mathrm{R}-1,91-93$ & 1417.8 & 2.1 & - & - & - & - & \\
\hline $149 \mathrm{R}-2,19$ & 1418.5 & 1.26 & -6.9 & 15.4 & 1.6 & 187 & \\
\hline 150R-1, 27 & 1426.7 & 1.42 & 9.6 & 13.3 & 2.1 & 153 & \\
\hline $150 \mathrm{R}-1,113$ & 1427.5 & 1.55 & - & 13.5 & 2.5 & 104 & \\
\hline $150 \mathrm{R}-1,116-118$ & 1427.6 & 3.0 & - & - & - & - & \\
\hline $150 \mathrm{R}-1,135$ & 1427.8 & 2.46 & 24.1 & 17.7 & 2.8 & 106 & \\
\hline $152 \mathrm{R}-1,123$ & 1437.1 & 1.78 & 8.1 & 18.9 & 2.1 & 75 & \\
\hline $153 \mathrm{R}-1,64$ & 1445.9 & 2.0 & -6.4 & 18.7 & 2.1 & 72 & \\
\hline $153 \mathrm{R}-2,9$ & 1446.9 & - & - & 15.5 & - & - & \\
\hline $154 \mathrm{R}-1,14$ & 1454.4 & 1.38 & 10 & 12.6 & 2.2 & 173 & \\
\hline $154 \mathrm{R}-1,62-64$ & 1454.9 & 2.3 & - & - & - & - & \\
\hline $154 \mathrm{R}-1,64$ & 1454.9 & - & 14.6 & 15.7 & - & - & \\
\hline $154 \mathrm{R}-1,76$ & 1455.0 & 1.99 & 16 & 17.5 & 2.3 & 143 & \\
\hline $155 \mathrm{R}-1,43$ & 1459.4 & 1.50 & -1.3 & 27.1 & 1.2 & 160 & 27 \\
\hline $158 \mathrm{R}-1,12$ & 1482.6 & 1.08 & -18.9 & 21.2 & 1.1 & 138 & \\
\hline $161 \mathrm{R}-1,4$ & 1504.1 & 1.73 & 7.7 & 21.1 & 1.8 & 102 & \\
\hline $161 \mathrm{R}-1,57$ & 1504.7 & 1.65 & 7.5 & 25.1 & 1.3 & 105 & 28 \\
\hline $162 \mathrm{M}-1,67-70$ & 1512.2 & 3.3 & - & - & - & - & \\
\hline $163 \mathrm{M}-1,43$ & 1512.0 & 1.83 & 7.8 & 35.6 & 1.1 & 140 & \\
\hline $163 \mathrm{M}-1,99$ & 1512.6 & 4.61 & -2 & 25.3 & 3.6 & 77 & \\
\hline $163 \mathrm{M}-2,6$ & 1513.2 & 1.36 & -3 & 25.2 & 1.1 & 148 & 29 \\
\hline $163 \mathrm{M}-2,17$ & 1513.3 & 2.44 & 2.2 & 31.2 & 1.7 & 160 & \\
\hline $163 \mathrm{M}-2,65-67$ & 1513.8 & 1.0 & - & - & - & - & \\
\hline $164 R-1,7$ & 1515.2 & 4.48 & 20.6 & 28.3 & 3.5 & 83 & \\
\hline $165 \mathrm{R}-1,29$ & 1529.8 & 1.36 & 12 & 19 & 1.4 & 148 & \\
\hline $169 \mathrm{R}-1,66$ & 1548.7 & 1.54 & 4 & 22.6 & 1.4 & 106 & 30 \\
\hline $169 \mathrm{R}-1,69-70$ & 1548.3 & 2.9 & - & - & - & - & \\
\hline $169 \mathrm{R}-1,80$ & 1548.4 & 2.08 & -8 & 25.4 & 1.6 & 127 & \\
\hline
\end{tabular}

(i.e., well within $12^{\circ}$; Cox and Doell, 1960), and no excursion occurred.

2. The depth of the thermoremanent blocking temperature isotherm (Nagata, 1961) is larger than the present penetration of Hole 504B.

3. Relative north-south motion of this part of lithosphere was smaller than the speed of the Nazca plate relative to South America (up to $10 \mathrm{~cm} / \mathrm{yr}$, the maximum average from the Creta- ceous to the present day; Larson and Pitsman, 1972). Therefore, the latitude of Site 504 has remained within $6^{\circ}$ of the equator over 5.93 Ma (Hobart et al., 1985), and the maximum probable change in the averaged inclination values resulting from the north-south drift is within a few (3.01) degrees.

The NRM inclination and its change with depth are schematically indicated at the top of Figure 7 . The ranges of the stable inclination of the individual core samples were used because the 
Table 4. Running average of rock magnetic values from this study for magnetic subunits 1a (top of basement) through 30 (total depth), Hole 504B. The rock magnetic groups are discussed in the text.

\begin{tabular}{|c|c|c|c|c|c|c|c|}
\hline $\begin{array}{l}\text { Magnetic } \\
\text { subunit }\end{array}$ & $\begin{array}{l}\text { Thickness } \\
\text { (m) }\end{array}$ & $\begin{array}{l}\text { Number } \\
\text { of } \\
\text { samples }^{a}\end{array}$ & $\begin{array}{c}\text { NRM } \\
\text { intensity } \\
(\mathrm{A} / \mathrm{m})\end{array}$ & $\begin{array}{c}\text { Stable } \\
\text { inclination } \\
\text { (degrees) }\end{array}$ & $\begin{array}{c}\text { Magnetic } \\
\text { susceptibility } \\
\left(\times 10^{-4} \mathrm{G} / \mathrm{Oe}\right)\end{array}$ & $\begin{array}{l}\text { Koenigsberger } \\
\text { ratio }\end{array}$ & $\begin{array}{l}\text { Magnetic } \\
\text { group }\end{array}$ \\
\hline $1 \mathrm{a}$ & 28.9 & 14 & $11.9 \pm 5.3$ & $-12 \pm 6$ & $9.4 \pm 4.2$ & $43 \pm 24$ & I \\
\hline Ib & 19.3 & 12 & $8.1 \pm 4.6$ & $-7 \pm 3$ & $12 \pm 4$ & $28 \pm 32$ & \\
\hline Ic & 10.6 & 2 & 16.0 & -14.5 & 12 & 53 & \\
\hline $2 a$ & 56.3 & 22 & $2.6 \pm 2.2$ & $-29 \pm 5$ & $14 \pm 3$ & $6 \pm 5$ & \\
\hline $2 b$ & 19.1 & 5 & $7.0 \pm 4.2$ & $-17 \pm 7$ & $13 \pm 4$ & $18 \pm 12$ & \\
\hline $2 c$ & 45.4 & 11 & $4.9 \pm 2.9$ & $-30 \pm 5$ & $13 \pm 3$ & $11 \pm 7$ & \\
\hline $2 d$ & 20.1 & 5 & $2.0 \pm 1.8$ & $-14 \pm 7$ & $21 \pm 6$ & $4 \pm 6$ & \\
\hline $2 \mathrm{e}$ & 38.6 & 9 & $4.8 \pm 3.0$ & $-36 \pm 12$ & $23 \pm 7$ & $7 \pm 5$ & \\
\hline 3 & 17.8 & 3 & $15.7 \pm 2.2$ & $9 \pm 6$ & $20 \pm 4$ & $25 \pm 5$ & II \\
\hline 4 & 27.3 & 12 & $3.5 \pm 2.5$ & $-26 \pm 8$ & $18 \pm 7$ & $9 \pm 10$ & \\
\hline 5 & 32.2 & 14 & $4.9 \pm 3.2$ & $7 \pm 3$ & $23 \pm 6$ & $6 \pm 3$ & \\
\hline $6 a$ & 16.7 & 4 & $1.8 \pm 1.5$ & $-64 \pm 11$ & $32 \pm 6$ & $1.6 \pm 1.3$ & \\
\hline $6 b$ & 28.1 & 4 & $8.1 \pm 4.4$ & $-42 \pm 10$ & $27 \pm 9$ & $11 \pm 7$ & \\
\hline 7 & 11.5 & 6 & $7.6 \pm 3.3$ & $6 \pm 4$ & $29 \pm 5$ & $7.4 \pm 3.5$ & \\
\hline $8 a$ & 14.5 & 4 & $8.9 \pm 3.3$ & $-27 \pm 8$ & $23 \pm 8$ & $13 \pm 6$ & \\
\hline $8 \mathrm{~b}$ & 27.3 & 4 & $7.8 \pm 9.9$ & $-13 \pm 4$ & $25 \pm 2$ & $12 \pm 17$ & \\
\hline $8 \mathrm{c}$ & 31.2 & 6 & $2.9 \pm 1.7$ & $-26 \pm 9$ & $35 \pm 6$ & $1.9 \pm 1.3$ & \\
\hline 9 & 18.2 & 6 & $1.6 \pm 1.0$ & $10 \pm 2$ & $33 \pm 3$ & $1.5 \pm 0.9$ & \\
\hline 10 & 9.4 & 2 & 6.9 & -20 & 26 & 10 & \\
\hline 11 & 41.3 & 8 & $13.0 \pm 0.7$ & $-63 \pm 17$ & $30 \pm 12$ & $21 \pm 22$ & \\
\hline 12 & 44.6 & 6 & $3.4 \pm 3.8$ & $-33 \pm 4$ & $43 \pm 14$ & $1.7 \pm 1.2$ & \\
\hline 13 & 65.1 & 13 & $0.88 \pm 0.67$ & $-15 \pm 7$ & $20 \pm 8$ & $1.4 \pm 1.2$ & III \\
\hline 14 & 120.4 & 25 & $0.10 \pm 0.19$ & $-21 \pm 24$ & $1.9 \pm 2.7$ & $1.5 \pm 1.5$ & \\
\hline 15 & 8.9 & 3 & $0.73 \pm 0.04$ & $9 \pm 3$ & $12 \pm 1$ & $1.6 \pm 0.2$ & \\
\hline 16 & 77.5 & 11 & $0.8 \pm 0.1$ & $-15 \pm 13$ & $6 \pm 5$ & $4.2 \pm 3.1$ & IV \\
\hline 17 & 27.1 & 4 & $1.3 \pm 0.3$ & $10 \pm 9$ & $15 \pm 2$ & $2.3 \pm 0.6$ & \\
\hline 18 & 8.6 & 2 & 1.35 & -10 & 17 & 2.2 & \\
\hline 19 & 174 & 3 & $2.1 \pm 0.3$ & $12 \pm 10$ & $16 \pm 5$ & $3.9 \pm 1.6$ & \\
\hline $20 \mathrm{a}$ & 23.2 & 3 & $1.6 \pm 0.6$ & $-11 \pm 10$ & $14 \pm 4$ & $3.0 \pm 0.3$ & \\
\hline $20 \mathrm{~b}$ & 28.7 & 2 & 0.9 & -3 & 13 & 2 & \\
\hline 21 & 47.9 & 6 & $1.3 \pm 0.3$ & $10 \pm 3$ & $9.4 \pm 1.7$ & $3.8 \pm 1.1$ & \\
\hline 22 & 9.9 & 4 & $0.77 \pm 0.09$ & $-8 \pm 4$ & $10 \pm 1.7$ & $2.0 \pm 0.05$ & \\
\hline 23 & 14.4 & 5 & $0.76 \pm 0.19$ & $1 \pm 3$ & $8.1 \pm 2.3$ & $2.3 \pm 0.6$ & \\
\hline 24 & 37.1 & 7 & $2.6 \pm 1.1$ & $23 \pm 10$ & $11 \pm 2$ & $4.7 \pm 2.9$ & \\
\hline 25 & 49.8 & 12 & $2.3 \pm 1.3$ & $-19 \pm 16$ & $16 \pm 7$ & $2.8 \pm 1.2$ & \\
\hline 26 & 72.1 & 18 & $2.0 \pm 0.5$ & $10 \pm 7$ & $17 \pm 1.8$ & $2.5 \pm 0.3$ & \\
\hline 27 & 23.2 & 2 & 1.3 & -11 & 24 & 1.1 & \\
\hline 28 & 8.5 & 3 & $2.1 \pm 0.8$ & $7.7 \pm 0.2$ & $27 \pm 7$ & $1.4 \pm 0.4$ & \\
\hline 29 & 1.2 & 3 & $2.8 \pm 1.7$ & $2 \pm 3$ & $27 \pm 3$ & $2.1 \pm 1.3$ & \\
\hline 30 & 34.6 & 4 & $2.2 \pm 1.3$ & $20 \pm 6$ & $24 \pm 4$ & $2.0 \pm 1.0$ & \\
\hline
\end{tabular}

${ }^{\text {a }}$ Of all collected samples, only those investigated for these parameters are listed.

present logging method gives no proper standard deviation factors for in-situ NRM inclination values. The reason that the downhole inclination values are not directly connected to in-situ NRM inclination values is clear in the method of conversion, equation (3) in the Appendix. The magnitudes of the outer radii of solid fans plotted in Figure 7 are approximately proportional to the average NRM intensities, and the angular spreads of the fans represent the ranges of the stable inclination of the core samples. We infer from the downhole changes in NRM that oceanic basement at Site 504 was significantly tilted by faulting due to tectonic processes.

\section{ACKNOWLEDGMENTS}

We would like to thank various people for providing their original data and papers, especially for the geochemical and magnetochemical petrographic studies: T. Akimoto, Makuhari Kita High School, Japan; S. Karato, Ocean Research Institute, University of Tokyo, Japan; and Y. Hamano, Earthquake Research Institute, University of Tokyo, Japan. Leg 111 co-chiefs K. Becker and H. Sakai and two anonymous reviewers provided critical suggestions and comments on our manuscript. We are grateful to the participants of DSDP/ODP cruises to Hole 504B for allowing the rock magnetists to have undisturbed fresh cores for the shipboard measurements program. Downhole measurements of the magnetic field were also encouraged and assisted by R. N. Anderson, LamontDoherty Geological Observatory, and the ODP marine technicians.

\section{REFERENCES}

Becker, K., Sakai, H., et al., 1988. Proc. ODP, Init. Repts., 111: College Station, TX (Ocean Drilling Program).

Cox, A., and Doell, R., 1960. Review of paleomagnetism. Geol. Soc. Am. Bull., 71:645-768.

Facey, D., Housden, J., and O'Reilly, W., 1985. A magneto-petrological study of rocks from Leg 83, Hole 504B, Deep Sea Drilling Project. In Anderson, R. N., Honnorez, J., Becker, K., et al., Init. Repts. $D S D P, 83$ : Washington (U.S. Govt. Printing Office), 339-346.

Furuta, T., 1983. Magnetic properties of basalt samples from Holes 504B and 505B on the Costa Rica Rift, Deep Sea Drilling Project, Legs 69 and 70. In Cann, J. R., Langseth, M. G., Honnorez, J., Von Herzen, R. P., White, S. M., et al., Init. Repts. DSDP, 69: Washington (U.S. Govt. Printing Office), 711-720.

1987. Is the oceanic crust over $1 \mathrm{~km}$ necessary for the source of marine magnetic anomalies. Phys. Earth Planet. Inter., 49:117120.

Furuta, T., and Levi, S., 1983. Basement paleomagnetism of Hole 504B. In Cann, J. R., Langseth, M. G., Honnorez, J., Von Herzen, R. P., White, S. M., et al., Init. Repts. DSDP, 69: Washington (U.S. Govt. Printing Office), 697-703.

Hamano, Y., and Kinoshita, H., in press. Measurements of three components of magnetic field in Hole 395A. In Detrick, R. S., Honnorez, J., Bryan, W. B., Juteau, T., et al., Proc. ODP, Sci. Results, 106/109: College Station, TX (Ocean Drilling Program). 
Hobart, M., Langseth, G., and Anderson, R., 1985. Geothermal and geophysical survey on the south flank of the Costa Rica Rift: Sites 504 and 505. In Anderson, R., Honnorez, J., Becker, K., et al., Init. Repts. DSDP, 83: Washington (U.S. Govt. Printing Office), 379399.

IAGA Division 1, Working Group 1, 1985. International Geomagnetic Reference Field revision 1985. J. Geomagn. Geoelectr., 37:1175-1164.

Johnson, H. P., 1979. Magnetization of the oceanic crust. Rev. Geophys., 17:215-226.

Johnson, H. P., and Pariso, J. E., 1985. Implications for a magnetic model of the ocean crust: new Troodos ophiolite data. EOS, Trans. Am. Geophys. Union, 66:128.

Kinoshita, H., Furuta, T., and Kawahata, H., 1985. Magnetic properties and alteration in basalt, Hole 504B, Deep Sea Drilling Project, Leg 83. In Anderson, R., Honnorez, J., Becker, K., et al., Init. Repts. DSDP, 83: Washington (U.S. Govt. Printing Office), 331338.

Larson, R. L., and Pitman, W. C., 1972. World-wide correlation of Mesozoic geomagnetic anomalies and its implications. Geol. Soc. Am. Bull., 83:3465-3662.

Nagata, T., 1961. Rock Magnetism (2nd ed.): Tokyo (Maruzen).

Parker, R. L., and Daniell, G. F., 1979. Interpretation of borehole magnetometer data. J. Geophys. Res., 84:5467-5479.

Pechersky, D. M., Tikhonov, L. V., and Pertsev, N. N., 1983. Magnetic properties of basalts, Deep Sea Drilling Project Legs 69 and 70. In Cann, J. R., Langseth, M. G., Honnorez, J., Von Herzen, R. P., White, S. M., et al., Init. Repts. DSDP, 69: Washington (U.S. Govt. Printing Office), 705-710.

Ponomarev, V. N., and Nekharoshkov, V. L., 1983. First measurements of the magnetic field within the ocean crust, Deep Sea Drilling Project Legs 68 and 69. In Cann, J. R., Langseth, M. G., Honnorez, J., Von Herzen, R. P., White, S. M., et al., Init. Repts. DSDP, 69: Washington (U.S. Govt. Printing Office), 271-279.

Smith, G. M., and Banerjee, S. K., 1986. The magnetic structure of the upper kilometer of the marine crust. J. Geophys. Res., 95:10,33310,354 .

Date of initial receipt: 29 March 1988

Date of acceptance: 10 January 1989

Ms 111B-141

\section{APPENDIX}

\section{Derivation of In-Situ Magnetization}

The magnetic field at the center of a cylindrical hole is produced by the surrounding materials, with the homogeneous magnetization

$$
\begin{aligned}
& F_{h}=\Pi M_{h}(\sin [a \tan (Z 2 / R)]-\sin [a \tan (Z 1 / R)]) \\
& F_{z}=-2 \Pi M_{z}(\sin [a \tan (Z 2 / R)]-\sin [a \tan (Z 1 / R)]),
\end{aligned}
$$

where the subscripts $h$ and $z$ denote horizontal and vertical components, respectively, $F$ is the magnetic field produced by the magnetization $(M)$ of surrounding materials, $R$ is a radius of the hole, and $Z 1$ and $Z 2$ are the depths of top and bottom of the layer filled with magnetic materials relative to the sensor (downward positive).

We assume that the downhole magnetic field $\left(F_{e x t}\right)$ is a composite value of the local geomagnetic field $\left(F_{\text {geo }}\right)$ and that produced by the $M$ of surrounding materials $\left(F_{m}\right)$ :

$$
F_{\text {ext }}=F_{\text {geo }}+F_{m}
$$

and

$$
F_{m}=G\left(\mathrm{NRM}+k F_{g e o}\right),
$$

where $G$ is given by the geometrical orientations $(\pi$ or $-2 \pi)$, as in equation (1). We obtain $F_{m}\left(=F_{\text {ext }}-F_{\text {geo }}\right)$ from downhole measurements. Thus, if the magnetic susceptibility $(k)$ is available, the NRM can be calculated from equation (3).

As in this investigation, if no in-situ susceptibility values are available, we have to use measurements from individual core samples.

\section{Is (deg.)}

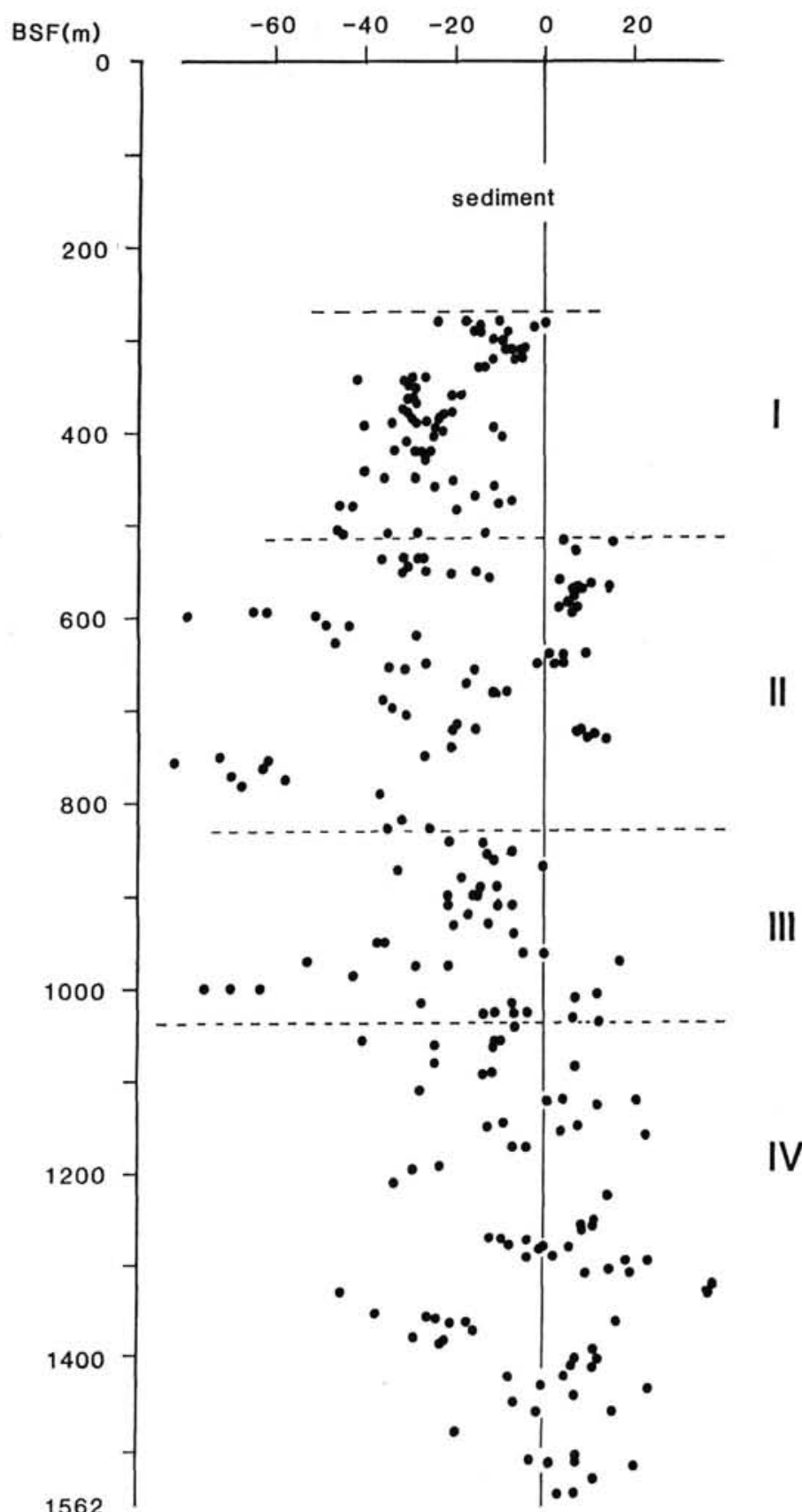

Figure 4. Stable inclination $\left(\mathrm{I}_{\mathrm{s}}\right)$ vs. depth below seafloor. Magnetic groups I through IV are labeled. 


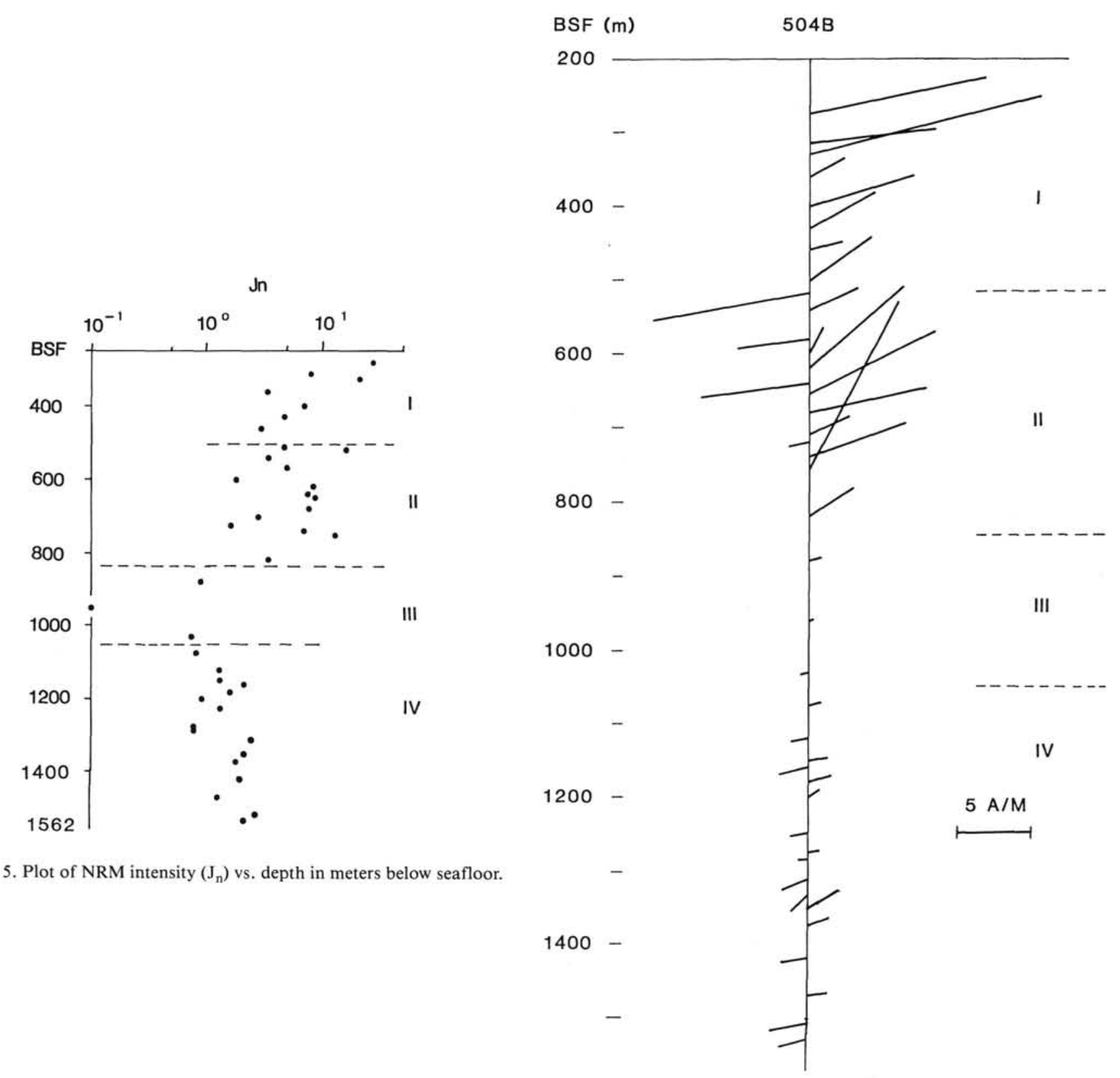

Figure 6. Semivector representation of combined stable inclinations and NRM intensities vs. depth in meters below seafloor. Negative values plot up and to the right, positive is down and to the left from the center. 
Table 5. Statistical results of Hole 504B magnetic data. Terms are defined in the text and Appendix.

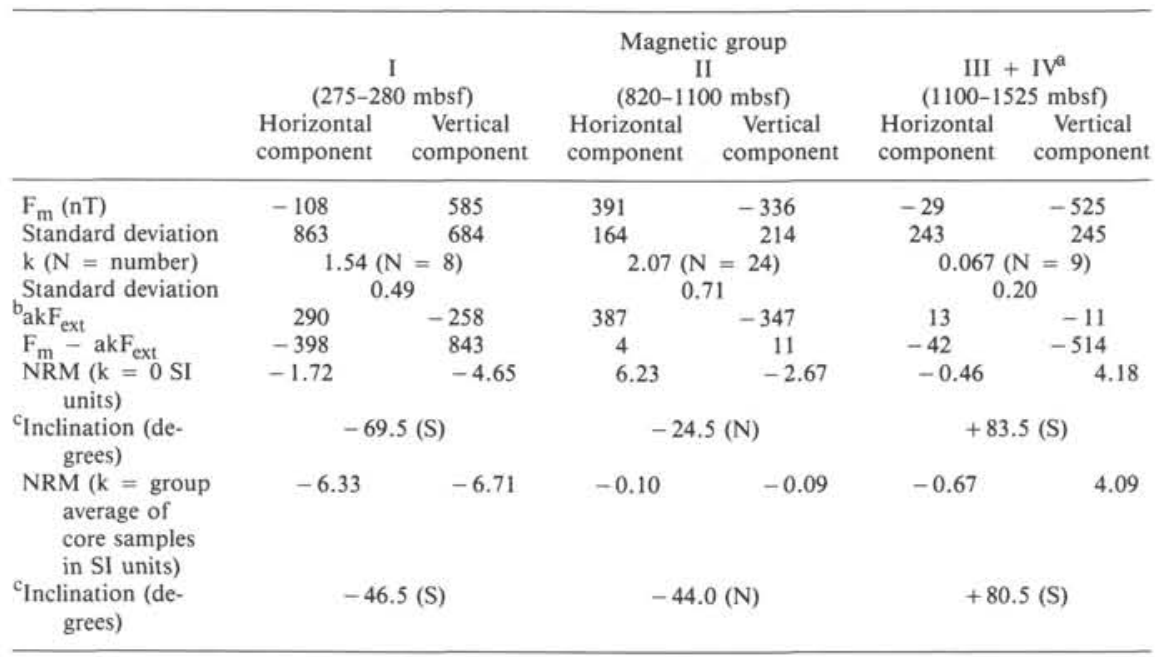

a Magnetic groups III and IV are combined, as discussed in the text.

$\mathrm{b} a=2$ for horizontal component and $\mathrm{a}=-4$ for vertical component.

${ }^{\mathrm{c}} \mathrm{S}=$ oriented south; $\mathrm{N}=$ oriented north.

Table 6. Paleomagnetic results from logged data compared to rock magnetic data from individual core samples. Terms defined in text, Appendix, and Table 5.

\begin{tabular}{|c|c|c|c|c|}
\hline & & \multicolumn{3}{|c|}{ Depth interval (mbsf) } \\
\hline & & $275-820$ & $820-1100$ & $1100-1525$ \\
\hline \multirow[t]{4}{*}{ Logging results } & In-situ NRM intensity & 0.93 & 0.013 & 0.40 \\
\hline & ${ }^{\mathrm{a}}$ Inclination & $\begin{array}{r}-46 \\
(S)\end{array}$ & $-44(N)$ & $+80(\mathrm{~S})$ \\
\hline & & \multicolumn{3}{|c|}{ Rock magnetic group } \\
\hline & & I & II & III + IV \\
\hline \multicolumn{5}{|c|}{ Paleomagnetism of core samples } \\
\hline & Number of samples & 31 & 38 & 2 \\
\hline & Average NRM intensity & 4.4 & 0.6 & 1.5 \\
\hline & ${ }^{b}$ Inclination & -20.2 & -14.6 & 3.2 \\
\hline & Standard deviation & 20.4 & 19.5 & 11.5 \\
\hline
\end{tabular}

${ }^{a}$ In degrees; $\mathrm{S}=$ oriented south; $\mathrm{N}=$ oriented north.

b In degrees; no azimuth can be defined. 


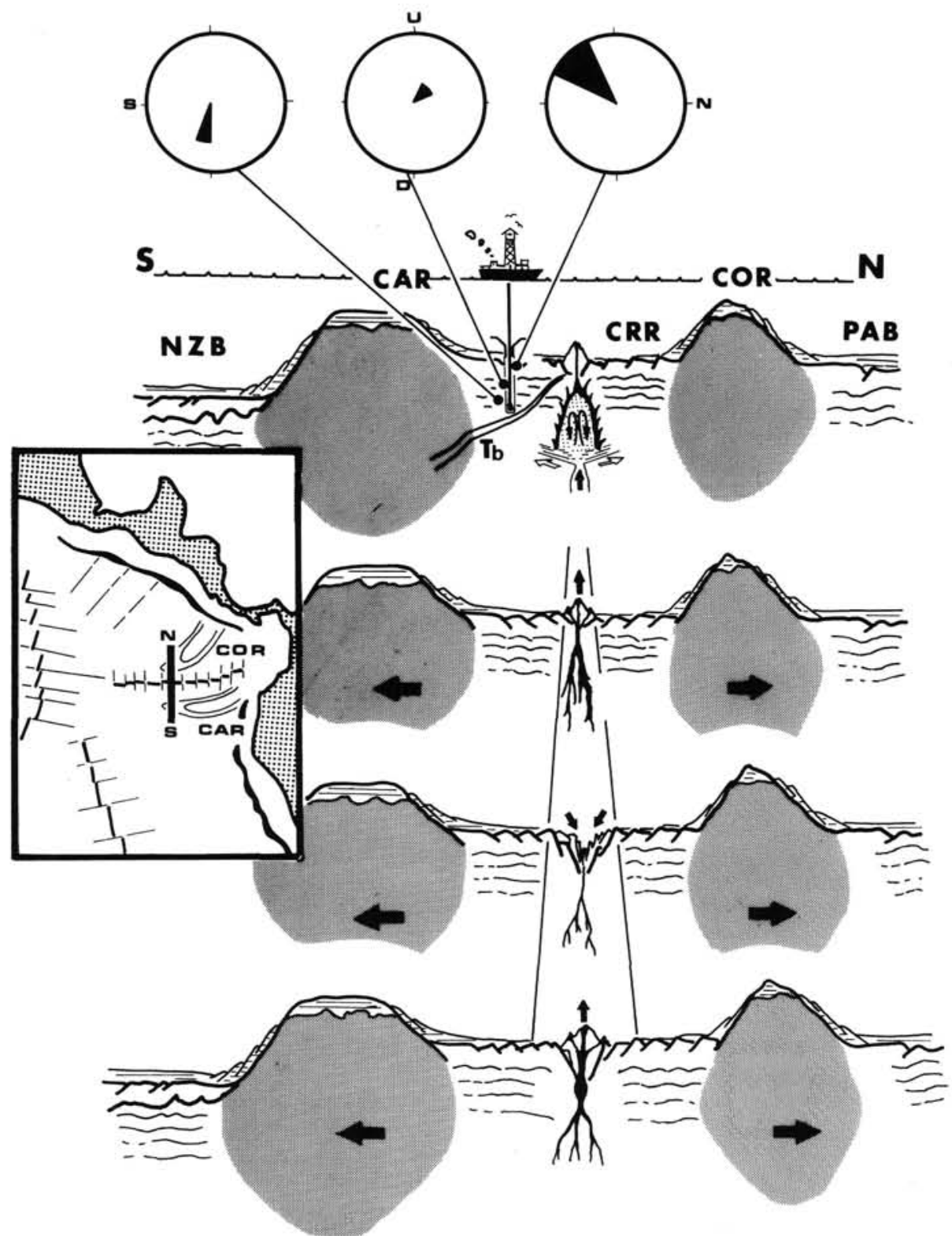

Figure 7. Hypothetical cross-section series of the lithosphere drawn along longitude $88^{\circ} \mathrm{W}$ (inset). $\mathrm{NZB}=$ Nazca Basin; $\mathrm{CAR}=$ Carnegie Ridge CRR = Costa Rica Rift COR = Cocos Ridge; PAB $=$ Pacific Basin; $T_{b}=$ depth of the isothermal level of the magnetic blocking temperature. The lower three cross sections show a sequence of upheaval and subsequent subsidence (small arrows) of the uppermost crust in the rift zone. The pair of subvertical lines connect identical areas of the crust affected by the spreading motion. The large arrows show the directions of relative spreading of the lithosphere. The change in the in-situ NRM inclination of the formations is shown at the top of the figure and discussed in the text. 